\title{
EQUITY
}

Vol. 23, No.1, 2020, 105-124

DOI: 10.34209/equ.v23i1.2205

P-ISSN 0216-8545 | E-ISSN 2684-9739

Diunggah : November 2020

Diterima : November 2020

Dipublikasi : November 2020

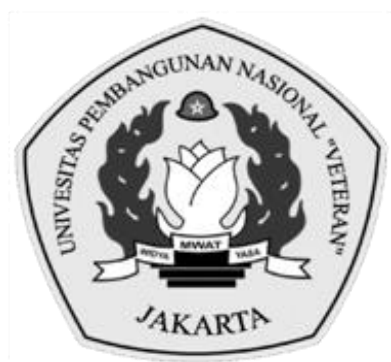

\section{FAKTOR YANG MEMPENGARUHI PERGANTIAN AUDITOR}

\author{
Nanda Agnes Mulyaningsih ${ }^{1 *}$, Dwi Jaya Kirana ${ }^{2}$, Ekawati Jati Wibawaningsih ${ }^{3}$ \\ 1nanda.agnes@upnvj.ac.id, 2dwijayakirana@upnvj.ac.id, 3ekawati.jati@upnvj.ac.id \\ 1, 2,3Universitas Pembangunan Nasional Veteran Jakarta, Indonesia \\ *Penulis Korespondensi
}

\begin{abstract}
Abstrak
Tujuan penelitan ini yakni untuk menganalisa pengaruh faktor auditee serta auditor kepada pergantian auditor. Populasi yang dipakai di penelitian ini yakni perusahaan manufaktur yang tercatat pada Bursa Efek Indonesia periode 2014-2018. Sampel penelitian dipilih memakai metode purposive sampling sehingga terkumpul sebanyak 54 perusahaan manufaktur sebagai sampel penelitian. Penelitian ini memakai teknik Analisis Regresi Logistik dalam uji hipotesis serta memakai bantuan program SPSS versi 25 guna mengolah data. Hasil penelitian ini mengindikasikan bahwa opini audit punya pengaruh negatif signifikan kepada pergantian auditor, sementara itu pergantian manajemen, pertumbuhan perusahaan, serta ukuran kantor akuntan publik tidak punya pengaruh signifikan kepada pergantian auditor.
\end{abstract}

Kata Kunci: Pergantian Manajemen; Pertumbuhan Perusahaan; Opini Audit; Ukuran Kantor Akuntan Publik; Pergantian Auditor.

\begin{abstract}
The purpose of this research is to analyze the effect of auditee and auditor factors on auditor turnover. The population used in this research is manufacturing companies listed on the Indonesia Stock Exchange in the 2014-2018 period. The research sample was selected using the purposive sampling method so as many as 54 manufacturing companies were collected as a research sample. This study uses the Logistic Regression Analysis technique in testing hypotheses and using the help of the SPSS version 25 program to process data. The results of this study indicate that audit opinion has a significant negative effect on auditor turnover, while management change, company growth, and the audit of public accounting firms have no significant effect on auditor turnover.
\end{abstract}

Keywords: Management Changing; Company Growth; Audit Opinion; Public Accounting Firm Size; auditor switching.

\section{PENDAHULUAN}

Laporan keuangan adalah hasil dari peristiwa akuntansi yang dapat digunakan sebagai informasi yang berguna antara data keuangan dan pemangku kepentingan untuk membuat keputusan. Fraudulent Financial Statement adalah masalah yang biasa terjadi di banyak perusahaan diseluruh dunia. Kondisi ekonomi dan politik di Indonesia dan dunia yang sangat fluktuatif belakangan ini mendorong para pelaku bisnis untuk melakukan fraud untuk menyajikan laporan keuangan yang baik di tengah-tengah kondisi yang tidak menguntungkan ini. dalam laporan keuangan untuk menyesatkan pengguna laporan keuangan $(A C F E$, 
dalam laporan keuangan untuk menyesatkan pengguna laporan keuangan ( $A C F E$, 2015). Fraudulent Financial Statement menyebabkan kerugian bagi pengguna laporan keuangan. Fraudulent Financial Statement tentu saja merugikan banyak pihak, baik perusahaan itu sendiri, investor dan juga merusak kepercayaan masyarakat serta reputasi dari perusahaan itu sendiri. Unsur-unsur yang dapat memengaruhi terjadinya fraudulent financial statetment (Ansar, 2013) diantaranya adalah earning management, financial distress, likuiditas, leverage, firm size, capital turnover dan profitabilitas. Penelitian ini hanya akan membahas likuiditas, leverage and firm size.

Likuiditas adalah contoh kemampuan perusahaan untuk melunasi utang jangka pendeknya (Hery, 2017 hlm.149). Perusahaan dengan likuiditas yang kurang dapat mendorong manajemen untuk membuat fraudulent financial statement. (Arifin dkk, 2016). Manajer akan bertindak dengan cara yang berbeda ketika perusahaan dalam kondisi yang buruk untuk menunjukkan kepada para pemegang saham bahwa situasi perusahaan itu sehat dan efisien, kemudian manajer akan melakukan fraudulent financial statement (Ansar, 2013). Hal ini sesuai dengan kondisi tekanan dalam fraud triangle theory, dimana manajer akan bertindak berbeda dengan melakukan fraudulent financial statement pada saat perusahaan berkinerja buruk untuk menunjukkan kepada investor bahwa kondisi perusahaan sehat dan sukses (Arifin dkk, 2016).

Leverage adalah penggunaan aset dan sumber keuangan yang biaya atau pengeluaran tetapnya berasal dari pinjaman untuk meningkatkan laba dan menunjukkan jumlah pembiayaan utang perusahaan (Hery, 2017 hlm.162). Hal yang sama juga disampaikan Kasmir (2013) dalam Mardianto dkk, yaitu saat perusahaan memiliki leverage yang tinggi dapat dikatakan bahwa perusahaan memiliki tingkat hutang yang tinggi dan risiko kredit yang tinggi. Risiko kredit yang tinggi dapat menimbulkan kekhawatiran bahwa perusahaan mungkin tidak dapat membayar kembali pinjaman. Akibatnya, perusahaan harus melindungi diri dari kondisi ini agar dapat membayar utangnya dengan melakukan fraudulent financial statement. Hal ini sejalan dengan fraud triangle dalam bentuk tekanan, tekanan berlebihan kepada manajemen untuk memenuhi kebutuhan atau harapan dari pihak yang berkepentingan, menjadikannya merupakan salah satu penyebab fraudulent financial statement, Tessa dan Harto dalam Setiawati dkk (2018).

Ukuran perusahaan merupakan pengukur yang menunjukkan besar atau kecilnya sebuah perusahaan. Hal yang sama juga disampaikan (Ansar, 2013) ukuran perusahaan dapat diukur berdasarkan total aset, total pendapatan, rata-rata total pendapatan, dan ekuitas. Ketika ukuran perusahaan tumbuh semakin besar maka permasalahan usaha yang dihadapi, tekanan, kepentingan, minat, tantangan dan sebagainya semakin besar dan sebaliknya. Sehingga ukuran perusahaan yang besar memungkinkan untuk membuat pihak manajemen melakukan fraudulent financial statement. Hal ini berhubungan dengan SAS 99 mengenai resiko kecurangan juga salah satunya dipengaruhi oleh ukuran perusahaan yang besar sehingga para manajer melakukan manipulasi agar laporan keuangannya agar terlihat baik oleh para pengguna.

Kasus-kasus fraud yang terjadi di dunia ini, misalnya Enron dan juga KAP Arthur Andersen yang menghebohkan dunia pada tahun 2001 silam yang menanggung banyak utang hingga harga saham Enron anjlok parah hingga US\$ 26 
cents dan juga kasus skandal akuntansi pada Toshiba Jepang yang baru saja terjadi tahun ini. Pada kenyataannya Indonesia juga tak luput dari maraknya kasus fraud. Sebut saja kasus Bank Global, Bank Lippo, dan Kimia Farma pada tahun 2000-an yang menodai integritas akuntan. Selain kasus tersebut, masih banyak kasus fraud lainnya yang terjadi. Jumlah perusahaan yang terlibat dalam kasus fraud pada laporan keuangan mungkin terlihat sangat sedikit, tetapi kasus yang terjadi sebenarnya bisa jadi jauh lebih banyak. Hal ini karena mungkin terdapat kasus yang terdeteksi namun tidak dilaporkan dan diselesaikan di luar pengadilan.

Pada 2015 kasus manipulasi laporan keuangan juga terjadi pada PT. Timah, Tbk. Pada laporan keuangan semester I tahun 2015 disebutkan bahwa efisiensi dan strategi yang telah membuahkan hasil yang positif. Padahal kenyataannya laporan keuangan pada semester I tahun 2015 laba operasi mengalami kerugian sebesar Rp 59 miliar. Selain mengalami penurunan laba, PT. Timah juga mencatatkan peningkatan utang hampir 100 persen dibanding 2013. Pada tahun 2013, utang perseroan hanya mencapai Rp 263 miliar. Namun, jumlah utang ini meningkat hingga Rp 2,3 triliun pada tahun 2015 (Egenius, 2016).

Kasus berikutnya terjadi di perusahaan PT. Inovasi Infracom, Tbk. Pada tahun 2014, ada insiden kecurangan dalam bentuk pembekuan pada saham perusahaan, karena laporan keuangan tahunan diklasifikasikan sebagai fraudulent financial statement. Bursa Efek Indonesia (BEI) telah mengidentifikasi sekitar delapan kesalahan dalam laporan keuangan Perusahaan Investasi pada kuartal ketiga 2014 karena manipulasi laporan keuangan. Sehingga PT Inovasi tidak memiliki cukup uang tunai (likuiditas) yang memadai untuk pembayaran kas kepada karyawan. BEI menemukan adanya perbedaan pembayaran kas kepada karyawan mencapai Rp 1,91 triliun, tapi pada periode kuartal III-2014 turun menjadi hanya Rp 59 miliar. BEI menyatakan bagian ini tidak tie up dengan laporan posisi keuangan. Perusahaan akan merevisi bagian ini yang tentu saja, atas kasus ini banyak pihak yang dirugikan (Angga, 2015).

Dalam likuiditas kasus gagal bayar industri keuangan kembali muncul lewat laporan hasil pemeriksaan 2016 Badan Pemeriksa Keuangan yang sudah memberikan peringatan. Pada saat itu, BPK telah menemukan investasi yang tidak tepat dalam pembelian saham yang salah karena data dasar perusahaan tidak akurat. Kekacauan Jiwasraya terungkap melalui laporan keuangan palsu. Laporan Jiwasraya yang tidak diaudit pada tahun 2017 awalnya membukukan laba bersih 2,4 triliun rupiah. Namun, setelah pergantian manajemen PricewaterhouseCoopers yang akhirnya merevisi auditnya. Laba bersih Jiwasraya turun menjadi 360 miliar rupiah. Masalah ini terjadi pada PT Asuransi Jiwasraya yang tengah terkena masalah likuiditas. Alhasil, perusahaan asuransi milik negara ini menunda pembayaran polis yang jatuh tempo dengan produk bancassurance asuransi jiwa yang berbalut investasi atau saving plan. Yang mana produk saving plan ini akan jatuh tempo pada Oktober 2018. Direktur Utama PT Asuransi Jiwasraya mengatakan, saving plan yang jatuh tempo dan tidak bisa dilunasi saat ini sebesar Rp 802 miliar. Namun PT Jiwasraya ini memiliki asset sebesar 75\% yang berupa saham, reksadana, surat berharga negara (SBN), dan obligasi. Dan memiliki 25\% asset lain yang berupa tanah dan property, yang menjadi persoalan adalah PT Jiwasraya tidak bisa mencairkan asetnya di saham karena pasar saham sedang mengalami tekanan (Dea, 2018). 
Dalam kasus leverage PT Sunprima Nusantara Pembiayaan (SNP Finance) menjadi sorotan otoritas keuangan dan publik. Perusahaan pembiayaan yang berada dibawah naungan Columbia Group tersebut diatas kertas terlihat dalam kondisi baik-baik saja. Rating utang perseroan sempat mendapatkan rating idA atau stabil dari Pefindo pada Maret 2018. Kemudian diduga pihak SNP Finance tidak menyampaikan laporan keuangan dengan benar alias fiktif, sehingga perusahaan pemeringkat dan auditor tidak mengeluarkan peringatan sehingga imbasnya Rating utang perseroan berubah drastis dari stabil menjadi idSD (selective default) pada 9 Mei 2018 lantaran salah satu kupon Medium Term Notes (MTN) yang diterbitkan SNP gagal bayar (Ringkang,2018).

Kasus Ukuran Perusahaan yang merujuk dari UU No. 20 Tahun 2008 pasal 6, perusahaan terbagi menjadi tiga kategori yaitu perusahaan besar (large firm), perusahaan sedang (medium-size) dan perusahaan kecil (small firm). Bank Perkreditan Rakyat (BPR) termasuk kedalam perusahaan dengan small-size. BPR mendapat perhatian khusus dari Otoritas Jasa Keuangan (OJK). Sebab, 80 persen kasus tindak pidana perbankan (fraud) terjadi di BPR. Kredit menjadi sumber mayoritas tindakan fraud, yakni mencapai 55 persen. Kasus fraud dengan tindakan fraudulent financial statement mencapai 21 persen dari total fraud. Lalu, penggelapan dana 15 persen, transfer uang 5 persen, dan pengadaan aset 4 persen. Pada 2016 hingga kuartal III, jumlah kasus fraud naik sedikit menjadi 26 kasus. Kendala dari terjadinya fraudulent financial statement ini karena size-nya kecil dan dilakukan pemeriksaan setahun sekali, tidak simultan seperti bank umum (Ardan, 2016).

Kesimpulan dari beberapa kasus tersebut terjadi perbedaan pencatatan pada laporan keuangan dengan kondisi yang sebenarnya sehingga mengindikasikan pemanipulasian laporan keuangan. Tindakan pemanipulasian laporan keuangan ini adalah merupakan salah satu bentuk tindakan fraudulent financial statement. Pelaporan keuangan yang mengandung fraudulent biasanya dilakukan dengan cara kesalahan yang berkaitan dengan jumlah, klasifikasi, penyajian, atau pengungkapan (Hery, 2017, hlm. 198).

Terdapat beberapa kajian hasil penelitian yang relevan dalam mendukung penelitian ini. Sesuai topik penelitian ini, maka penelitian terdahulu yang dikemukakan disini adalah yang berkaitan dengan Fraudulent Financial Statement. Hasil penelitian tersebut nantinya digunakan sebagai gambaran bagi peneliti untuk melaksanakan penelitian. Penelitian ini mengacu pada penelitian terdahulu yang berkaitan dengan fraudulent financial statement yang dilakukan oleh Listiyawati (2016) mendapatkan hasil bahwa likiuditas tidak berpengaruh terhadap laporan keuangan sedangkan penelitian Ansar (2011) mendapatkan hasil bahwa likuiditas berpengaruh negatif terhadap fraudulent financial statement.

Menurut penelitian dari Finamaya dkk (2014) dan Ansar (2011) yang mendapatkan hasil bahwa leverage berpengaruh positif pada fraudulent financial statement sedangkan penelitian Prasetyo (2014) mendapatkan hasil bahwa leverage tidak berpengaruh terhadap fraudulent financial statement.

Penelitian dari Prasetyo (2014), Ansar (2011) dan Owens-Jackson et. al. (2009) mendapatkan hasil bahwa ukuran perusahaan berpengaruh positif terhadap fraudulent financial statement dan sementara penelitian Carcello et. al. (2004) dan Finamaya dkk (2014) mendapatkan hasil bahwa ukuran perusahaan berpengaruh 
negatif terhadap fraudulent financial statement sedangkan hasil penelitian Handoko dan Ramadhani (2017) mendapatkan hasil bahwa ukuran perusahaan tidak berpengaruh terhadap fraudulent financial statement.

Berdasarkan latar belakang dan hasil penelitian sebelumnya yang belum konsisten, peneliti tertarik untuk meneliti dan menguji kembali tentang pengaruh likuiditas, leverage dan ukuran perusahaan terhadap fraudulent financial statement. Adapun perbedaan penelitian yang akan dilakukan dengan pengujian-pengujian dengan masalahnya yang terletak pada pembaharuan periode.

\section{TINJAUAN PUSTAKA}

Jensen dan Meckling (1976) menyatakan bahwa hubungan keagenan adalah sebuah kontrak antara manajer (agent) dengan pemilik (principal). Hubungan agensi muncul ketika satu orang atau lebih (principal) yang memiliki kepentingan untuk memperkerjakan orang lain (agent) dengan maksud memberikan jasa dan kemudian seluruh wewenang dan keputusan mengenai perusahaan itu ada pada agent melalui persetujuan dari principal. Dalam sebuah perusahaan, manajer berperan sebagai agent yang secara moral bertanggung jawab untuk mengoptimalkan keuntungan para pemilik (principal), namun disisi yang lain manajer juga mempunyai kepentingan memaksimumkan kesejahteraan mereka (Ujiyantho \& Pramuka, 2007). Conflict of interest atau perbedaan kepentingan antara principal dan agent inilah yang dapat memicu agency problem yang dapat mempengaruhi kualitas laba yang dilaporkan. Dalam teori keagenan menjelaskan tentang dua pelaku ekonomi yang saling bertentangan yaitu principal dan agent. Jika principal dan agent memiliki tujuan yang sama maka agent akan mendukung dan melaksanakan semua yang diperintahkan oleh principal.

Teori keagenan pada dasarnya merupakan teori yang muncul karena adanya konflik kepentingan antara principal dan agent. Teori ini mengasumsikan bahwa antara principal dan agent memiliki motivasi tersendiri untuk kepentingan dirinya sendiri sehingga menimbulkan konflik kepentingan antara principal dan agent. Principal mengontrak agent untuk melakukan pengelolaan sumber daya dalam perusahaan dan berkewajiban untuk memberikan imbalan kepada agent sedangkan agent berkewajiban melakukan pengelolaan sumber daya yang dimiliki oleh perusahaan dan bertanggung jawab atas tugas yang dibebankan kepadanya (lane, dalam marheni, 2017). Berdasarkan teori ini, terjadi pemisahan antara pemilik (principal) dan pengelola perusahaan (agent) sehingga menimbulkan agency problem. Selanjutnya pemisahan pemilik dan pengelola juga menimbulkan asimetri informasi yaitu suatu keadaan dimana agent memiliki akses informasi yang tidak dimiliki oleh pihak principal. Asimetri informasi muncul ketika agent lebih banyak mengetahui informasi internal dan prospek masa yang akan datang, dibandingkan pengetahuan tentang informasi yang diketahui oleh principal dan stakeholder lainnya (Wenny, 2016).

Rasio likuiditas adalah kemampuan perusahaan untuk melunasi kewajiban jangka pendek tepat pada waktunya. Apabila semakin besar kemampuan perusahaan dalam membayar hutang jangka pendeknya maka akan mempengaruhi berbagai kemungkinan perusahaan akan mendapatkan pembiayaan dari para 
kreditur jangka pendek untuk mengoperasikan kegiatan usahanya. Hery (2017, hlm.149) rasio likuiditas adalah rasio yang menunjukkan kemampuan perusahaan dalam memenuhi kewajiban atau membayar utang jangka pendeknya. Dengan kata lain, rasio likuiditas adalah rasio yang dapat digunakan untuk mengukur sampai seberapa jauh tingkat kemampuan perusahaan dalam melunasi kewajiban jangka pendeknya yang akan segera jatuh tempo.

Perusahaan dengan kondisi tingkat likuiditasnya yang lebih rendah dapat memotivasi pihak manajemen untuk melakukan fraudulent financial statement. Hal ini sesuai dengan kondisi tekanan yang dalam teori segitiga kecurangan, dimana manajer akan bertindak untuk melakukan berbagai cara ketika perusahaan berada dalam kondisi tidak berkinerja baik sehingga untuk menunjukkan kepada pihak pemegang saham bahwa kondisi perusahaan sehat dan sukses, maka manajer akan melakukan fraudulent financial statement. Hal ini sesuai dengan yang dikemukakan oleh Kreutzfeldt dan Wallace dalam Arifin (2016), yang mengemukakan bahwa perusahaan dengan masalah likuiditas memiliki kesalahan yang lebih signifikan dalam laporan keuangannya daripada perusahaan lain yang tidak mengalami masalah likuiditas.

Leverage adalah penggunaan aset dan sumber keuangan yang biaya atau pengeluaran tetapnya berasal dari pinjaman untuk meningkatkan laba dan menunjukkan jumlah pembiayaan utang perusahaan (Hery, 2017 hlm.162). Menurut Kasmir (2013 hlm.151) rasio solvabilitas atau leverage ratio merupakan rasio yang digunakan untuk mengukur sejauh mana aktiva perusahaan dibiayai dengan hutang. Artinya berapa besar beban utang yang ditanggung perusahaan dibandingkan dengan aktivanya. Dalam arti luas dikatakan bahwa rasio solvabilitas digunakan untuk mengukur kemampuan perusahaan untuk membayar seluruh kewajibannya, baik jangka pendek maupun jangka panjang apabila perusahaan dibubarkan (dilikuidasi).

Hal yang sama juga disampaikan Kasmir (2013) dalam Mardianto dkk, yaitu saat perusahaan memiliki leverage yang tinggi dapat dikatakan bahwa perusahaan memiliki tingkat hutang yang tinggi dan risiko kredit yang tinggi. Risiko kredit yang tinggi dapat menimbulkan kekhawatiran bahwa perusahaan mungkin tidak dapat membayar kembali pinjaman. Akibatnya, perusahaan harus melindungi diri dari kondisi ni agar dapat membayar utangnya dengan melakukan fraudulent financial statement. Hal ni sejalan dengan fraud triangle dalam bentuk tekanan, tekanan berlebihan kepada manajemen untuk memenuhi kebutuhan atau harapan dari pihak yang berkepentingan, menjadikannya merupakan salah satu penyebab fraudulent financial statement, Tessa dan Harto dalam Setiawati dkk (2018).

Ukuran perusahaan merupakan ukuran besar kecilnya perusahaan yang ditunjukan atau dinilai oleh total asset, total penjualan, jumlah laba, beban pajak dan lain-lain. Ukuran perusahaan (firm size) adalah besar kecilnya perusahaan dapat diukur dengan total aktiva/besar harta perusahaan dengan menggunakan perhitungan nilai logaritma total aktiva (Hartono dalam Susilantino, 2014).

Ukuran perusahaan dapat diukur dengan logaritma natural dari nilai buku dari total aset pada akhir tahun fiskal. Ukuran perusahaan selain menunjukkan mengenai total aset dan omzetnya juga menunjukkan mengenai kompleksitas dalam berbagai macam hal yang harus dihadapi oleh manajemen, misalnya ketika skala usaha perusahaan semakin besar maka permasalahan usaha yang dihadapi, 
tekanan, kepentingan, tantangan dan sebagainya akan menjadi semakin besar juga, begitupun sebaliknya.

Perusahaan yang besar cenderung lebih dapat mengakses pasar modal untuk memperoleh pendanaan. Dengan kemudahaan tersebut perusahaan memiliki flesibilitas dan kemampuan untuk memperoleh dana (Wahidayati dalam Carla 2016). Menurut Carla (2016) Ukuran perusahaan yang besar memiliki target untuk menghasilkan laba yang besar pula, ketika perusahaan tersebut telah mencapai targetnya berarti perusahaan tersebut mampu menghasilkan laba yang besar. Dan ketika laba yang dihasilkannya melebihi dari yang tergetkan, maka selisih dari laba yang dihasilkan dengan target perusahaan dapat dimanipulasi oleh manajer. Berdasarkan pemaparan diatas, maka hipotesis penelitian ini adalah likuiditas, leverage, dan ukuran perusahaan berpengaruh terhadap fraudulent financial statement.

\section{Pengembangan Hipotesis}

Pengembangan hipotesis ini merupakan model konseptual tentang bagaimana teori berhubungan dengan berbagai faktor yang telah diidentifikasi sebagai masalah yang penting. Rasio likuiditas adalah rasio yang menunjukkan kemampuan perusahaan dalam memenuhi kewajiban atau membayar utang jangka pendeknya, Hery (2017, hlm.149). Semakin tinggi rasio ini menunjukan semakin mampu perusahaan dalam memenuhi kewajiban yang segera harus dibayar. Namun bila terlampau tinggi, akan berpengaruh jelek terhadap kemampulabaan perusahaan, karena ada sebagian dana yang tidak produktif yang diinvestasikan dalam current assets. Suatu perusahaan dikatakan likuid apabila perusahaan tersebut mempunyai kekuatan membayar (berupa current assets) sedemikian besarnya sehingga mampu memenuhi segala kewajiban jangka pendeknya yang segera harus dipenuhi (berupa current liabilities) (Abdul Halim dalam Arifin 2016).

Perusahaan dengan kondisi tingkat likuiditasnya yang lebih rendah dapat memotivasi pihak manajemen untuk melakukan fraudulent financial statement. Hal ini sesuai dengan kondisi tekanan yang dalam teori segitiga kecurangan, dimana manajer akan bertindak untuk melakukan berbagai cara ketika perusahaan berada dalam kondisi tidak berkinerja baik sehingga untuk menunjukkan kepada pihak pemegang saham bahwa kondisi perusahaan sehat dan sukses, maka manajer akan melakukan fraudulent financial statement (Omeye dan Eragbhe dalam Arifin 2016). Hal ini sejalan dengan yang dikemukakan oleh Kreutzfeldt dan Wallace dalam Arifin (2016), yang menemukan bahwa perusahaan dengan masalah likuiditas memiliki pengaruh yang lebih signifikan dalam laporan keuangannya daripada perusahaan lain yang tidak mengalami masalah likuiditas.

Leverage adalah penggunaan asset dan sumber dana yang berasal dari pinjaman dengan maksud untuk meningkatkan keuntungan dan menunjukkan proporsi seberapa perusahaan dibiayai oleh hutang (Hery, 2017, hlm.162). Financial leverage menunjukkan utang yang dimiliki oleh suatu perusahaan. Perusahaan akan memperkecil angka financial leverage untuk menghindari kreditur tidak meminjamkan dana lagi kepada perusahaan. Hal ini akan dilakukan oleh manajer atau bagian keuangan dengan cara merubah laporan keuangannya. Hal sama disampaikan dari hasil penelitian yang dilakukan Anisa dalam Susmita dan 
Nanik (2015) menunjukkan bahwa leverage memiliki pengaruh yang signifikan dengan fraudulent financial statement.

Perusahaan yang besar cenderung lebih dapat mengakses pasar modal untuk memperoleh pendanaan. Dengan kemudahaan tersebut perusahaan memiliki fleksibilitas dan kemampuan untuk memperoleh dana (Hutomo dan Sudarno dalam Carla 2016). Menurut Ngurah dan Merta (2016) Ukuran perusahaan dapat dinyatakan dengan total asset yang di miliki oleh perusahaan. Wallace et. al. dalam Devi dan Ketut (2014) ukuran perusahaan dapat mempengaruhi kelengkapan pengungkapan laporan keuangannya. Skala usaha perusahaan semakin besar maka permasalahan usaha yang dihadapi, tekanan, kepentingan, tantangan dan sebagainya akan menjadi semakin besar juga, begitupun sebaliknya. Sehingga ukuran perusahaan yang besar cenderung untuk membuat pihak manajemen melakukan fraudulent financial statement. Menurut hasil penelitian Rangga dalam Eka dan Erni (2008) menunjukkan bahwa ukuran perusahaan memiliki pengaruh terhadap fraud dalam pelaporan keuangan.

Berdasarkan uraian di atas, gambaran menyeluruh penelitian ini yang mengangkat penelitian mengenai pengaruh dalam mendeteksi fraudulent financial statement.

Berdasarkan alur-alur lojik pada pengembangan hipotesis diatas maka hipotesis dapat disimpulkan sebagai berikut:

H1: Likuiditas berpengaruh signifikan terhadap Fraudulent Financial Statement

H2: Leverage berpengaruh signifikan terhadap Fraudulent Financial Statement

H3: Ukuran Perusahaan berpengaruh signifikan terhadap Fraudulent Financial Statement

\section{METODOLOGI PENELITIAN}

Populasi di riset ini yakni perusahaan manufaktur yang telah tercantum dalam BEI di tahun 2015-2018. Dalam riset ini metode pengambilan sampel yang dipakai yakni nonprobability sampling yang memanfaatkan metode purposive sampling. Bersumber pada Sugiono (2017) purposive sampling yakni metode pemilihan sampel pada karakteristik terpilih. Sumber data yang dipakai yakni laporan keuangan tahunan audited pada periode 2015-2018. Laporan tahunan audited bisa didapatkan dari halaman website resmi IDX (www.idx.co.id) ataupun dapat diakses melalui halaman website resmi dari perusahaan tersebut. Bersumber pada kriteria sampel yang sudah ditentukan dengan memakai metode purposive sampling sehingga yang didapatkan sebanyak 54 perusahaan manufaktur dengan masa penelitian empat tahun yaitu 2015-2018, sebanyak 216 sampel digunakan pada penelitian ini. 
Mulyaningsih, Kirana, dan Wibawaningsih, Faktor yang Mempengaruhi...

Tabel 1. Kriteria Pemilihan Sampel

\begin{tabular}{lc}
\hline \multicolumn{1}{c}{ Keterangan } & Jumlah \\
\hline $\begin{array}{l}\text { Perusahaan manufaktur yang tercatat pada BEI yang akan menjadi } \\
\text { sampel }\end{array}$ & 142 \\
\hline Perusahaan yang mempublikasi laporan keuangan tidak menyeluruh & $(30)$ \\
\hline Perusahaan yang tidak menyajikan informasi secara lengkap & $(15)$ \\
\hline $\begin{array}{l}\text { Perusahaan yang tidak melangsungkan pergantian auditor secara } \\
\text { voluntary }\end{array}$ & $(33)$ \\
\hline Perusahaan yang tidak menyajikan laporan auditor independen & $(5)$ \\
\hline Data ekstrem yang teroutlier & $(5)$ \\
\hline Jumlah sampel setiap periode & 54 \\
\hline Rentang waktu penelitian & 4 \\
\hline Total sampel akhir & 216 \\
\hline Sumber: Data Diolah (2020)
\end{tabular}

Teknik analisis pada penelitian ini menggunakan Microsoft Excel 2019 serta SPSS versi 25 dengan metode analisis regresi logistik sebab variabel terikat pada riset ini mempunyai sifat nonmetrik. Penelitian ini dilakukan pengujian melalui bermacam uji statistik yang mencakup atas statistik deskriptif pengujian asumsi klasik beserta analisis regresi logistik. Model regresi yang di bentuk dari penelitian ini bersumber pada analisis regresi logistik yakni:

\section{Rumus 1. Model Penelitian}

$\operatorname{Ln} \underline{\text { Switch }}=\alpha+\beta_{1}$ MNG CHANGE $+\beta_{2}$ GROWTH $+\beta_{3}$ OPINION $+\beta_{4}$ SIZE KAP + e $\ldots \ldots$. (1) (1-Switch)

Keterangan:

$\begin{array}{ll}\text { Ln } \underline{\text { Switch }} & \text { : Pergantian Auditor } \\ \alpha & \\ \text { MNG CHANGE } & : \text { Konstanta } \\ \text { GROWTH } & : \text { Pergantian Manajemen } \\ \text { OPINION } & : \text { Pertumbuhan Perusahaan. } \\ \text { SIZE KAP } & : \text { Ukuran Audit } \\ \beta_{1}-\beta_{4} & : \text { Koefisien regresi variabel bebas } \\ \mathrm{e} & : \text { Error }\end{array}$

\section{Pengukuran Variabel}

Variabel Dependen

Variabel dependen dalam riset ini ialah pergantian auditor. Pengukuran variabel terikat di riset ini melalui variable dummy, bila perusahaan melaksanakan pergantian auditor dengan cara voluntary sehingga diberi angka 1 . Sementara itu angka 0 buat perusahaan yang tidak melaksanakan pergantian auditor. Riset ini 
dilakukan dengan mengetahui auditor yang melakukan audit ditahun sebelumnya pada laporan auditor independen.

\section{Variabel Independen}

Variabel independen dalam riset ini pergantian manajemen, pertumbuhan perusahaan, opini audit, dan ukuran kap. Pergantian manajemen (X1): Apabila perusahaan melangsungkan pergantian manajemen seperti digantinya presiden direktur atau direktur utama diberi angka 1. Sementara itu perusahaan yang tidak melaksanakan pergantian presiden direktur atau direktur utama diberikan angka 0 . Penelitian ini melihat direktur utama atau presiden direktur yang menjabat pada periode sebelumnya. Pertumbuhan Perusahaan (X2): Rasio tingkat penjualan digunakan sebagai proksi dari variabel pertumbuhan perusahaan dengan rumus:

Keterangan:

$$
d S=\frac{S_{t}-S_{t-1}}{S_{t-1}}
$$

$d S$ = Rasio pertumbuhan perusahaan

$S_{t}=$ Penjualan bersih di tahun disaat pergantian auditor

$S_{t-1}=$ Penjualan bersih di tahun disaat sebelum pergantian auditor

Opini audit (X3): Dalam riset ini ketika perusahaan memperoleh pendapat wajar tanpa pengecualian sehingga dibagikan angka 1 serta angka 0 terhadap opini selain wajar tanpa pengecualian. Ukuran KAP (X4): Bila KAP berafiliasi terhadap BigFour sehingga dibagikan angka 1, sementara itu untuk KAP yang tidak punya afiliasi terhadap BigFour akan dibagikan angka 0.

\section{HASIL DAN PEMBAHASAN}

\section{Analisis Statistik Deskriptif}

Hasil uji statistik deskriptif menunjukkan, telah didapatkan sejumlah 216 data pengamatan yang bersumber atas perkalian diantara masa penelitian sepanjang 4 tahun yakni sejak 2015-2014 yang memiliki jumlah sampel sejumlah 54 perusahaan.

Tabel 2. Hasil Uji Statistik Deskriptif

\begin{tabular}{llrrcr}
\hline & N & Minimum & Maximum & Mean & Std. Deviation \\
\hline Growth & 216 & -0.5314 & 3.7824 & 0.093997 & 0.3068475 \\
\hline
\end{tabular}

Valid N (listwise) 216

Sumber: Data Diolah (2020)

Hasil uji statistik deskriptif kepada variabel pertumbuhan perusahaan memperlihatkan nilai minimal sejumlah -0,5314, nilai maksimal sejumlah 3,78241, nilai mean sejumlah 0.093997 serta standar deviasi sejumlah 0,3068475. 
Mulyaningsih, Kirana, dan Wibawaningsih, Faktor yang Mempengaruhi...

Tabel 3. Statistik Frekuensi Pergantian Manajemen

\begin{tabular}{rlrrrr}
\hline & Frequency & Percent & Valid Percent & $\begin{array}{c}\text { Cumulative } \\
\text { Percent }\end{array}$ \\
\hline \multirow{3}{*}{ Valid } & Tidak_Melakukan & 193 & 89.4 & 89.4 & 89.4 \\
\cline { 2 - 6 } & $\begin{array}{l}\text { Melakukan_Perga } \\
\text { ntian }\end{array}$ & 23 & 10.6 & 10.6 & 100 \\
\cline { 2 - 6 } & Total & 216 & 100 & 100 & \\
\hline
\end{tabular}

Sumber: Data Diolah (2020)

Bersumber dari tabel frekuensi tersebut bisa dilihat mengenai hasil uji statistik frekuensi memperlihatkan $89,4 \%$ atau 193 sampel perusahaan tidak mengganti susunan manajemennya, sedangkan $10,6 \%$ nya lagi atau 23 sampel perusahaan melakukan pergantian susunan manajemen pada masa observasi. Artinya perusahaan manufaktur di Indonesia yang tidak melaksanakan pergantian manejemen paling banyak daripada perusahaan manufaktur yang melaksanakan pergantian manajemen.

Tabel 4. Statistik Frekuensi Opini Audit

\begin{tabular}{llrrrr}
\hline & Frequency & Percent & Valid Percent & \multicolumn{2}{c}{$\begin{array}{c}\text { Cumulative } \\
\text { Percent }\end{array}$} \\
\hline \multirow{3}{*}{ Valid } & Other_WTP & 87 & 40.3 & 40.3 & 40.3 \\
\cline { 2 - 6 } & WTP & 129 & 59.7 & 59.7 & 100 \\
\cline { 2 - 6 } & Total & 216 & 100 & 100 & \\
\hline
\end{tabular}

Sumber: Data Diolah (2020)

Bersumber pada tabel frekuensi tersebut bisa diketahui mengenai hasil uji statistik frekuensi terdapat 87 sampel perusahaan yang melakukan penerimaan terhadap opini selain wajar tanpa pengecualian (WTP) atau sebesar 40,3\%, sedangkan sisanya sebanyak 129 sampel perusahaan melakukan penerimaan terhadap pendapat wajar tanpa pengecualian ataupun sejumlah 59,7\%. Artinya perusahaan manufaktur di Indonesia yang menerima pendapat wajar tanpa pengecualian (WTP) paling banyak dibandingkan perusahaan manufaktur yang mendapat opini audit selain wajar tanpa pengecualian.

Tabel 5. Statistik Frekuensi Ukuran Kantor Akuntan Publik

\begin{tabular}{llrrrr}
\hline & Frequency & Percent & Valid Percent & \multicolumn{2}{c}{$\begin{array}{c}\text { Cumulative } \\
\text { Percent }\end{array}$} \\
\hline \multirow{2}{*}{ Valid } & Non_Big_4 & 106 & 49.1 & 49.1 & 49.1 \\
\cline { 2 - 6 } & Big_4 & 110 & 50.9 & 50.9 & 100 \\
\cline { 2 - 6 } & Total & 216 & 100 & 100 & \\
\hline
\end{tabular}

Sumber: Data Diolah (2020) 
Bersumber dari tabel frekuensi tersebut bisa diketahui terkait hasil uji statistik frekuensi terdapat 106 sampel perusahaan yang tidak memakai KAP yang punya afiliasi terhadap BigFour atau sebesar 49,1\%, sedangkan sisanya terdapat 110 sampel perusahaan yang memakai KAP yang punya afiliasi terhadap BigFour atau sebesar 50,9\% pada masa observasi. Artinya perusahaan manufaktur di Indonesia yang memakai KAP yang punya afiliasi dengan BigFour semakin banyak dibandingkan perusahaan manufaktur yang memakai perusahaan KAP yang tidak punya afiliasi terhadap BigFour.

Tabel 6. Statistik Frekuensi Pergantian Auditor

\begin{tabular}{llrrrr} 
& & Frequency & Percent & $\begin{array}{c}\text { Valid } \\
\text { Percent }\end{array}$ & $\begin{array}{c}\text { Cumulativ } \\
\text { e Percent }\end{array}$ \\
\hline \multirow{2}{*}{ Valid } & Tidak_Melakukan & 66 & 30.6 & 30.6 & 30.6 \\
\cline { 2 - 6 } & $\begin{array}{l}\text { Melakukan_ } \\
\text { Pergantian }\end{array}$ & 150 & 69.4 & 69.4 & 100 \\
\cline { 2 - 6 } & Total & 216 & 100 & 100 & \\
\hline
\end{tabular}

Sumber: Data Diolah (2020)

Berdasarkan tabel frekuensi diatas dapat diketahui bahwa hasil uji statistik frekuensi terdapat 66 sampel perusahaan yang tetap menggunakan auditor sebelumnya atau sebesar 30,6\%, sedangkan sisanya sebanyak 150 sampel perusahaan yang mengganti auditornya atau sebesar $69,4 \%$. Artinya perusahaan manufaktur di Indonesia yang melangsungkan pergantian auditor eksternalnya lebih dari dua kali lebih banyak dibandingkan perusahaan manufaktur yang mengganti auditornya hanya dua kali.

\section{Uji Multikolonieritas}

Multikolinieritas bisa terlihat menggunakan VIF (Variance Inflatin Factor) serta nilai Tolerance. Apabila nilai VIF kurang daripada 10 serta nilai Tolerance lebih daripada 0,10, sehingga model bisa dinyatakan tidak mengandung unsur atas multikolinieritas serta bisa dipakai pada penelitian (Ghozali, 2018).

Tabel 7. Hasil Uji Multikolonieritas

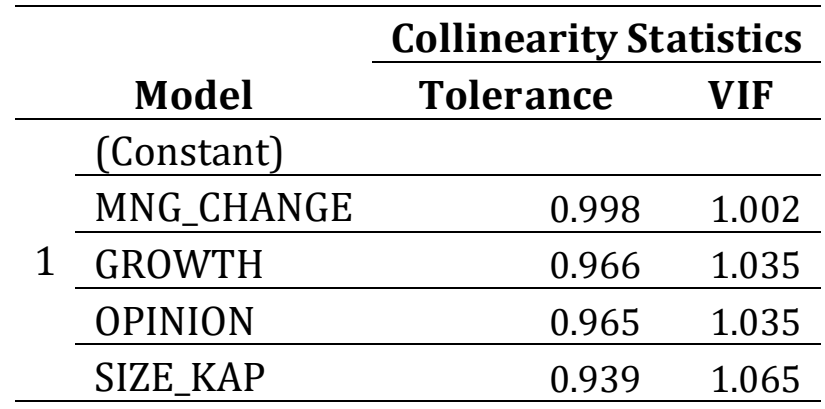

a. Dependent Variable: SWITCH

Sumber: Data Diolah (2020) 
Bersumber atas tabel Uji Multikolinearitas tersebut menunjukkan seluruh variable bebas pada penelitian ini punya nilai $\mathrm{VIF}<10$ serta nilai Tolerance $>0,10$. Sehingga bisa ditarik kesimpulan mengenai seluruh variabel tidak terdapat korelasi diantara variabel atau tidak terjadi multikolonieritas.

\section{Menilai Keseluruhan Model}

Dengan terdapatnya penurunan diantara nilai -2 Log Likehood awal dan nilai -2 Log Likehood akhir memperlihatkan mengenai model regresi yang dijadikan hipotesis fit terhadap data. Hasil uji bisa diketahui di tabel seperti berikut:

Tabel 8. Hasil Uji -2Log Likelihood Block Number $=0$

\begin{tabular}{crrr}
\hline Iteration & \multicolumn{2}{c}{ Log Likelihood } & \multicolumn{2}{c}{ Coefficients Contant } \\
& 1 & 265.981 & 0.778 \\
Step 0 & 2 & 265.895 & 0.821 \\
& 3 & 265.895 & 0.821 \\
\hline
\end{tabular}

a. Nilai konstan termasuk ke dalam model ini

b. -2 Log Likehood awal sebesar 265.895

c. Estimasi diakhiri pada iterasi nomor 3 karena estimasi parameter mengalami perubahan yang berkurang dari .001

Sumber: Data Diolah (2020)

Tabel 9. Hasil Uji-2Log Likelihood Block Number = 1

\begin{tabular}{lrrrrrrr} 
Iteration & & $\begin{array}{c}-2 \mathrm{Log} \\
\text { Likelihood }\end{array}$ & Constant & MNG_CHANGE & GROWTH & OPINION & SIZE_KAP \\
\hline \multirow{3}{*}{ Step 1 } & 1 & 256.87 & 1.276 & -0.196 & -0.377 & -0.727 & -0.016 \\
\cline { 2 - 8 } & 2 & 256.291 & 1.474 & -0.232 & -0.419 & -0.903 & -0.02 \\
\cline { 2 - 8 } & 3 & 256.289 & 1.485 & -0.234 & -0.42 & -0.914 & -0.02 \\
\cline { 2 - 8 } & 4 & 256.289 & 1.485 & 0.234 & -0.42 & -0.914 & -0.02 \\
\hline
\end{tabular}

a. Method: Enter

b. Nilai konstan termasuk ke dalam model ini

c. -2 Loglikehood awal sebesar 265.895

d. Estimasi diakhiri pada iterasi nomor 4 karena estimasi parameter mengalami perubahan yang berkurang dari .001

Sumber: Data Diolah (2020)

Bersumber pada perhitungan -2 Log Likehood awal (Block Number $=0$ ) memiliki nilai sejumlah 265,895 serta -2 Log Likehood akhir (Block Number =1) memiliki nilai sejumlah 256,289 yang menunjukkan terdapatnya penurunan nilai diantara -2 Log Likehood awal serta akhir sejumlah 9,606 dapat dinyatkan model fit terhadap data.

\section{Uji Kelayakan Model Regresi}


Kelayakan model regresi dengan nilai statistik Hosmer and Lemeshow Goodness of Fit lebih besar dari 0,05 bisa dikatakan hipotesis nol bisa diterima sebab sejalan terhadap data observasi.

Tabel 10. Hasil Uji Hosmer and Lemeshow Test

\begin{tabular}{cccc}
\hline Step & Chi-square & df & Sig \\
\hline 1 & 2.919 & 8 & 0.939 \\
\hline Sumber: Data Diolah (2020) & &
\end{tabular}

Bersumber pada tabel tersebut bisa dikeahui mengenai Chi-square 2,919 dengan nilai signifikansi sejumlah 0,939 dengan df 8. Nilai signifikansi yang telah didapatkan sudah mencukupi prasyarat dengan nilai lebih besar dari 0,05 sehingga hipotesis nol tidak bisa ditolak ataupun dapat dikatakan model diterima.

\section{Koefisien Determinasi}

Uji koefisien determinasi adalah pengujian yang dilaksanakan guna melihat sebesar apa variabel bebas bisa punya pengaruh kepada variabel terikat memakai nilai Nagelkerke R Square (Ghozali, 2018).

Tabel 11. Hasil Uji Nagelkerke's R Square

\section{Step -2 Log Likelihood Cox \& Snell R Square Nagelkerke R Square}

$1256.289^{a} \quad 0.043 \quad 0.061$

a. Estimasi diakhiri pada iterasi nomor 4 karena estimasi parameter berubah kurang dari .001

Sumber: Data Diolah (2020)

Hasil uji model summary menunjukkan -2 Log Likehood sebesar 256,289 atas koefisien determinasi yang dapat diketahui berdasarkan nilai Nagelkerke $R$ Square sejumlah 0,061 dengan Cox \& Snell R Square sejumlah 0,043.

\section{Matriks Klasifikasi}

Matriks klasifikasi dipakai guna mengetahui keakuratan perkiraan atas model regresi untuk memperkirakan peluang perusahaan manufaktur untuk melakukan pergantian auditor (Ghozali, 2018). 
Tabel 12. Kekuatan Prediksi

Predicted

SWITCH

\begin{tabular}{lllllr}
\hline & & $\begin{array}{c}\text { Tidak_Melak } \\
\text { ukan }\end{array}$ & $\begin{array}{c}\text { Melakukan_Perg } \\
\text { antian }\end{array}$ & $\begin{array}{c}\text { Percent } \\
\text { age } \\
\text { Correct }\end{array}$ \\
\hline $\begin{array}{l}\text { Step } \\
1\end{array}$ & $\begin{array}{l}\text { SWIT } \\
\text { CH }\end{array}$ & $\begin{array}{l}\text { Tidak_Melakuka } \\
\text { n }\end{array}$ & 1 & 65 & 1.5 \\
\hline & $\begin{array}{l}\text { Melakukan_Perg } \\
\text { antian }\end{array}$ & 0 & & 150 & 100 \\
\hline & Overall Percentage & 0 & & 69.9 \\
\hline
\end{tabular}

a. The cut value is .500

Sumber: Data Diolah (2020)

Kapabilitas prediksi dari model regresi diatas terhadap perusahaan yang melaksanakan pergantian auditor sebesar 150 atau 100\%. Sementara itu kapabilitas perkiraan untuk perusahaan yang tidak melaksanakan pergantian auditor yakni sejumlah 1,5\%. Keakuratan dari prediksi keseluruhan model ini ialah sebesar 69.9\%.

\section{Uji Model Regresi}

Uji hipotesis tersebut menggunakan model pengujian regresi logistik yang bisa terlihat dan ditampilkan dalam tabel sebagai berikut:

Tabel 13. Hasil Uji Model Regresi

\begin{tabular}{rlrrrrrr} 
& \multicolumn{7}{c}{ Variables in the Equation } \\
& B & \multicolumn{1}{c}{ S.E. } & Wald & Df & \multicolumn{1}{c}{ Sig. } & Exp(B) \\
\hline \multirow{3}{*}{ Step 1a } & MNG_CHANGE & -0.234 & 0.475 & 0.241 & 1 & 0.623 & 0.792 \\
\cline { 2 - 8 } & GROWTH & -0.42 & 0.508 & 0.685 & 1 & 0.408 & 0.657 \\
\cline { 2 - 8 } & OPINION & -0.914 & 0.331 & 7.63 & 1 & 0.006 & 0.401 \\
\cline { 2 - 8 } & SIZE_KAP & -0.02 & 0.312 & 0.004 & 1 & 0.948 & 0.98 \\
\cline { 2 - 8 } & Constant & 1.485 & 0.311 & 22.79 & 1 & 0 & 4.417 \\
\hline
\end{tabular}

a. Variable(s) entered on step 1: MNG_CHANGE, GROWTH, OPINION, SIZE KAP. Sumber: Data Diolah (2020)

Bersumber pada tabel 13 sehingga model regresi yang terwujud yakni seperti berikut:

Ln $\underline{\text { Switch }}=1,485-0,234$ MNG_CHANGE-0,420GROWTH-0,9140PINION (1Switch) 0,020SIZE_KAP + e 
Keterangan:

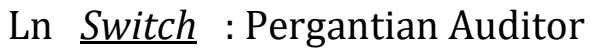

(1-Switch)

$\begin{array}{ll}\alpha & : \text { Konstanta } \\ \text { PM } & : \text { Pergantian Manajemen } \\ \text { PP } & : \text { Pertumbuhan Perusahaan } \\ \text { OPINI } & : \text { Opini Audit } \\ \text { KAP } & : \text { Ukuran KAP } \\ \beta_{1}-\beta_{4} & : \text { Koefisien regresi variabel independen } \\ \text { e } & : \text { Error }\end{array}$

\section{Pembahasan}

Pengaruh Pergantian Manajemen kepada Pergantian Auditor

Hasil uji regresi logistik memperlihatkan mengenai pergantian manajemen mempunyai koefisien regresi negatif senilai $-0,234$ beserta tingkat signifikansi 0,623 lebih besar daripada 0,05 . Hasil uji hipotesis pertama $\left(\mathrm{H}_{1}\right)$ memperlihatkan mengenai hipotesis ditolak, artinya pergantian manajemen tidak mempunyai pengaruh kepada pergantian auditor untuk perusahaan manufaktur yang tercatat pada BEI periode waktu 2015-2018.

Hal ini sesuai dengan pendapat yang dinyatakan dalam penelitian Adli \& Suryani (2019) bahwa pada saat pengambilan ketetapan Rapat Umum Pemegang Saham (RUPS), manajemen baru dan investor mempertimbangkan kebijakan yang lama terkait auditor eksternalnya, jika ada kesesuaian antara manajemen baru dan auditor eksternal dalam bekerjasama maka tidak diperlukan pergantian auditor.

Hasil riset ini menunjang hasil riset Sari et al. (2018) serta penelitian Adli \& Suryani (2019). Hasil penelitian memperlihatkan mengenai pergantian manajemen tidak punya pengaruh kepada pergantian auditor. Berbanding terbalik dengan penelitian Pradhana \& Suputra (2015) dan penelitian Manto \& Manda (2018) yang memiliki hasil penelitian mengenai pergantian manajemen punya pengaruh positif kepada pergantian auditor yang menyatakan bahwa terdapatnya ketidaksesuaian antara manajemen dengan auditor terkait dengan isu akuntansi tertentu maka perusahaan memilih untuk melakukan pergantian manajemen.

Pengaruh Pertumbuhan Perusahaan kepada Pergantian Auditor

Hasil uji regresi logistik memperlihatkan mengenai pertumbuhan perusahaan memiliki koefisisen regresi negatif senilai $-0,420$ beserta tingkat signifikansi sejumlah 0,408 lebih besar daripada 0,05. Hasil uji hipotesis memperlihatkan mengenai hipotesis kedua $\left(\mathrm{H}_{2}\right)$ ditolak, artinya pertumbuhan perusahaan tidak mempunyai perngaruh kepada pergantian auditor untuk perusahaan manufaktur yang telah tercatat pada BEI periode waktu 2015-2018.

Hasil penelitian tersebut mendukung penelitian dari Maryani et al. (2016) dengan hasil penelitian mengenai pertumbuhan perusahaan tidak berpengaruh kepada pergantian auditor serta menyatakan bahwa manajemen tidak akan mengganti auditornya jika auditor tersebut dianggap dapat memahami kondisi perusahaan dengan baik. Berbanding terbalik pada riset yang dilaksanakan Faradila \& Yahya (2016) serta Soraya \& Haridhi (2017) yang memiliki hasil riset bahwa pertumbuhan perusahaan punya pengaruh positif kepada pergantian auditor yang 
menyatakan bahwa semakin meningkatnya pertumbuhan suatu perusahaan hingga keinginan perusahaan untuk melangsungkan pergantian auditor makin banyak terjadi guna meningkatkan kebutuhan dan memenuhi kebutuhan perusahaan.

Pengaruh Opini Audit kepada Pergantian Auditor

Hasil uji regresi logistik memperlihatkan mengenai opini audit mempunyai koefisien regresi negatif senilai $-0,914$ beserta tingkat signifikansi sejumlah 0,006 lebih kecil daripada 0,05. Hasil pengujian hipotesis tersebut memperlihatkan mengenai hipotesis ketiga $\left(\mathrm{H}_{3}\right)$ diterima, artinya opini audit memiliki pengaruh kepada pergantian auditor kepada perusahaan manufaktur yang tercatat pada BEI dalam rentang waktu 2015-2018.

Hasil penelitian ini menunjang penelitian Uslifah \& Hanafie (2016) dengan hasil penelitian yang memperlihatkan mengenai opini audit punya pengaruh negatif kepada pergantian auditor serta menyatakan bahwa manajemen akan melaksanakan pergantian auditor guna memperoleh opini yang diharapkan, dengan strategi mengganti auditornya maka informasi yang tidak menguntungkan mengenai kondisi perusahaan tidak dipublikasi kepada investor. Berbanding terbalik pada penelitian yang dilaksanakan Faradila \& Yahya (2016), serta penelitian Alisa et al. (2019). Hasil riset memperlihatkan bahwa pendapat audit punya pengaruh positif kepada pergantian auditor menyatakan mengenai opini audit yang diterima mempengaruhi perusahaan agar mengganti auditor untuk mendapat opini audit yang diinginkan.

\section{Pengaruh Ukuran Kantor Akuntan Publik kepada Pergantian Auditor}

. Hasil uji regresi logistik menampakkan mengenai ukuran KAP mendapati koefisien regresi negatif senilai $-0,020$ serta nilai signifikan sejumlah 0,948 lebih besar daripada 0,05. Hasil uji hipotesis itu memperlihatkan hipotesis keempat tidak diterima atau ditolak, artinya ukuran KAP tidak punya pengaruh kepada pergantian auditor untuk perusahaan manufaktur yang tercantum di BEI periode waktu 20152018.

Hasil penelitian ini menunjang penelitian Wijaya \& Rasmini (2015) yang mengemukakan mengenai ukuran KAP bukan acuan perusahaan agar melaksanakan pergantian auditor dengan hasil penelitian memperlihatkan mengenai ukuran KAP tidak punya pengaruh kepada pergantian auditor. Berbanding terbalik dengan riset yang dilaksanakan Maryani et al. (2016) serta Manto \& Manda (2018). Hasil dari riset ini memperlihatkan mengenai ukuran kantor publik mempunyai pengaruh negatif kepada pergantian auditor menyatakan mengenai perusahaan akan melakukan pemilihan kepada KAP yang punya afiliasi terhadap BigFour untuk menjaga reputasi perusahaan.

\section{SIMPULAN}

Berdasarkan pada hasil uji yang sudah dilaksanakan menggunakan program SPSS versi 25, penelitian ini membuktikkan bahwa pergantian manajemen, pertumbuhan perusahaan, ukuran KAP tidak mempunyai pengaruh secara signifikan terhadap terjadinya pergantian auditor. Hal ini disebabkan karena dengan terjadinya pergantian manajemen, pertumbuhan perusahan dan 
penggunaan ukuran KAP tidak selalu diiringi dengan terjadinya pergantian auditor. Berbeda dengan opini audit yang mempunyai pengaruh secara signifikan atas terjadinya pergantian auditor.

Dalam penelitian ini terdapat keterbatasan yang mampu dijadikan materi evaluasi bagi peneliti berikutnya supaya hasil riset yang didapatkan semakin baik. Keterbatasan pada riset ini masih terdapat perusahaan yang tidak mempublikasi dan menyajikan laporan tahunan audited dengan lengkap, serta tidak banyak perusahaan yang telah melakukan pergantian auditor secara sukarela atau voluntary yang dilakukan karena keinginan klien. Adanya keterbatasanketerbatasan yang telah disampaikan dapat mengurangi jumlah sampel yang diperlukan dalam riset ini.

Saran teoritis untuk penelitian berikutnya direkomendasikan menambahkan variabel lainnya yang mempunyai pengaruh terhadap pergantian auditor misal biaya audit, ukuran perusahaan, audit delay. Dan dapat memperluas objek penelitian serta rentang waktu penelitian agar sampel penelitian yang didapatkan semakin banyak. Saran praktisnya ialah perusahaan hendaknya memperhatikan hal-hal yang dapat timbul dari terjadinya pergantian auditor dan untuk para investor hendaknya memperhatikan hal-hal yang memicu perusahaan tersebut melakukan pergantian auditor.

\section{DAFTAR PUSTAKA}

Adli, S. N., \& Suryani, E. (2019). Pengaruh Leverage, Pergantian Manajemen, dan Audit Fee Terhadap Auditor Switching. Jurnal Asset, 11(2), 288-300.

Agustian, W. (2009). Schering Plough Ganti Akuntan Publik. Retrieved March 5, 2020, from www.economy.okezone.com website: https://economy.okezone.com/read/2009/11/18/278/276700/scheringplough-indonesia-ganti-akuntan-publik

Alisa, I. A., Devi, I. A. R., \& Brillyandra, F. (2019). The Effect of Audit Opinion, Change of Management, Financial Distress and Size of a Public Accounting Firm on Auditor Switching. Jurnal Akuntansi Trisakti, 6(1), 55.

Diana. (2019). Faktor-Faktor Yang Mempengaruhi Auditor Switching Pada Perusahaan Non Keuangan. Jurnal Bisnis Dan Akuntansi, 20(2), 141-148.

Faradila, Y., \& Yahya, M. R. (2016). Pengaruh Opini Audit, Financial Distress , dan Pertumbuhan Perusahaan Klien Terhadap Auditor Switching ( Studi pada Perusahaan Manufaktur yang Terdaftar di Bursa Efek Indonesia Tahun 20102014 ). Jurnal Ilmiah Mahasiswa Ekonomi Akuntansi, 1(1).

Ghozali, I. (2018). Aplikasi Analisis Multivariate Dengan Program IBM SPSS 25. Semarang: Badan Penerbit Universitas Diponegoro.

Manto, J. I., \& Manda, D. L. (2018). Pengaruh Financial Distress , Pergantian Manajemen dan Ukuran KAP Terhadap Auditor Switching. Jurnal Media Riset Akuntansi, Auditing \& Informasi, 18(2), 205-224.

Maryani, S., Respati, N. W., \& Safrida, L. (2016). Pengaruh Financial Distress, Pertumbuhan Perusahaan, Rentabilitas, Ukuran KAP, dan Ukuran Perusahaan Terhadap Pergantian Auditor. Jurnal Reviu Akuntansi Dan Keuangan, 6(2), 873884. 
Messier, W. F., Glover, S. M., \& Prawitt, D. F. (2014). Jasa Audit dan Assurance (8th ed.). Salemba Empat.

Nazri, S. N. F. S. M., Smith, M., \& Ismail, Z. (2012). Factors influencing auditor change : evidence from Malaysia. Journal Asian Review of Accounting.

Otoritas Jasa Keuangan. POJK No.13-POJK.03-2017 tentang Penggunaan Jasa Akuntan Publik dan Kantor Akuntan Publik. , (2017).

Pradhana, M. A. B., \& Suputra, I. D. . D. (2015). Pengaruh Audit Fee, Going Concern, Financial Distress, Ukuran Perusahaan, Pergantian Manajemen pada Pergantian Auditor. E-Jurnal Akuntansi Universitas Udayana, 3, 713-729.

Safriliana, R., \& Muawanah, S. (2019). Faktor yang Memengaruhi Auditor Switching di Indonesia. Jurnal Akuntansi Aktual, 5(3), 234-240.

Sari, A. K., Deviyanti, D. R., \& Kusumawardani, A. (2018). Faktor-Faktor yang Mempengaruhi Voluntary Auditor Switching pada Perusahaan yang terdaftar di bei periode 2010-2015. Jurnal Akuntabel, 15(1), 17.

Soraya, E., \& Haridhi, M. (2017). Faktor-Faktor Yang Mempengaruhi Voluntary Auditor Switching ( Studi Empiris pada Perusahaan Non Financing yang Terdaftar di Bursa Efek Indonesia tahun 2011-2015 ). Jurnal Ilmiah Mahasiswa Ekonomi Akuntansi, 2(1).

Sugiyono, P. D. (2017). Metode Penelitian Kuantitatif, Kualitatif, dan R\&D. Bandung: Alfabeta.

Uslifah, R., \& Hanafie, H. (2016). Auditor Switching Perusahaan Manufaktur di Bursa Efek Indonesia. Jurnal Assets, 6(36), c.30.

Wea, A., \& Murdiawati, D. (2015). Faktor-Faktor Yang Mempengaruhi Auditor Switching Secara Voluntary Pada Perusahaan Manufaktur. Jurnal Ekonomi Dan Bisnis, 22(9), 154-170.

Wijaya, E., \& Rasmini, N. K. (2015). Pengaruh Audit Fee, Opini Going Concern, Financial Distress, Ukuran Perusahaan, Ukuran Kap Pada Pergantian Auditor. E-Jurnal Akuntansi Universitas Udayana, 11(3), 940-966. 
EQUITY, Vol. 23, No.1, 2020, 105-124

Halaman ini sengaja dikosongkan untuk kepentingan penggenapan halaman 